\title{
Chiral Separation, X-ray Structure and Biological Evaluation of a Potent and Reversible Dual Binding Site AChE Inhibitor
}

Marco Catto $^{1, *}$, Leonardo Pisani ${ }^{1}$, Eugenio de la Mora ${ }^{2}$, Benny Danilo Belviso ${ }^{3}$, Giuseppe Felice Mangiatordi ${ }^{3}$, Andrea Pinto ${ }^{4}$, Annalisa De Palma ${ }^{5}$ Nunzio Denora ${ }^{1}$, Rocco Caliandro ${ }^{3}$, JacquesPhilippe Colletier ${ }^{2}$, Israel Silman ${ }^{6}$, Orazio Nicolotti $^{1}$, Cosimo Damiano Altomare $^{1}$

${ }^{1}$ Department of Pharmacy-Drug Sciences, University of Bari Aldo Moro, Via E. Orabona 4, 70125, Bari, Italy

${ }^{2}$ Univ. Grenoble Alpes, CEA, CNRS, Institute of Structural Biology, F-38044 Grenoble, France.

${ }^{3}$ Institute of Crystallography, National Research Council (CNR), Via G. Amendola 122/O, 70126 Bari, Italy

${ }^{4}$ Department of Food, Environmental and Nutritional Sciences (DeFENS), University of Milan, Via Celoria 2, 20133 Milano (Italy).

5 Department of Biosciences, Biotechnologies and Biopharmaceutics, University of Bari Aldo Moro, Via E. Orabona 4, 70125, Bari, Italy

${ }^{6}$ Department of Neurobiology, Weizmann Institute of Science, 7610001 Rehovot, Israel.

\section{Supporting Information}




\section{Materials and methods}

\section{Chemistry}

Starting materials, reagents and analytical grade solvents were commercially available and purchased from Merck Sigma-Aldrich, Milan, Italy. All reactions were routinely monitored with thin layer chromatography (TLC) on aluminum sheets (Merck Kieselgel $60 \quad \mathrm{~F}_{254}$ ); spots were displayed through UV lamp. For reactions requiring anhydrous environment, glassware was preliminary dried by heating on flame burner and then by cooling under argon stream. Chromatographic separations were performed by means of gravitational chromatography, using 63$200 \mu \mathrm{m}$ silica (Merck). Chiral HPLC analyses were performed using a Kromasil 5-AmyCoat column (4.6 mm i.d. $\times 250 \mathrm{~mm}$, AkzoNobel), fitted to a Jasco PU-980 pump and a Jasco UV-975 detector (Jasco Europe, Cremella, Italy). Runs were carried out in 1/1 (v/v) hexane/iPrOH at a flow rate of $1 \mathrm{~mL} / \mathrm{min}$, monitoring the eluate at $220 \mathrm{~nm}$. Preparative chiral HPLC was performed with a Kromasil 5-AmyCoat column (21.2 mm i.d. $\times 250 \mathrm{~mm}$, Hichrom, Milan, Italy), fitted to a 1525 Extended Flow Binary HPLC pump and a Waters 2489 UV/Vis detector (both from Waters, Milan, Italy). Solvent was in $1 / 1(\mathrm{v} / \mathrm{v})$ hexane/iPrOH, at a flow rate of $15 \mathrm{~mL} / \mathrm{min}$, monitoring the eluate at $220 \mathrm{~nm} .{ }^{1} \mathrm{H}-\mathrm{NMR}$ spectra were recorded in the specified deuterated solvent at $500 \mathrm{MHz}$ on an Agilent 500/54 Premium Shielded instrument (Agilent Technologies, Milan, Italy). Chemical shifts are expressed in $\delta(\mathrm{ppm})$ and coupling constants $\mathrm{J}$ in Hertz $(\mathrm{Hz})$. The following abbreviations were used: s (singlet), t (triplet), qn (quintuplet), m (multiplet), br (broad signal); signals due to $\mathrm{NH}$ protons were located by deuterium exchange with $\mathrm{D}_{2} \mathrm{O}$. Melting points (MP) were determined by the capillary method on a Stuart Scientific SMP3 electrothermal apparatus (Bibby Scientific, Milan, Italy) and are uncorrected. Mass spectra were obtained with a dual electrospray interface (ESI) and a quadrupole time-of-flight mass spectrometer (Q-TOF, Agilent 6530 Series Accurate-Mass Quadrupole Time-of-Flight LC/MS, Agilent Technologies, Milan, Italy). Elemental analyses were performed on a Euro EA 3000 analyzer (Eurovector, Milan, Italy). Optical rotations were measured on a PerkinElmer 341 spectropolarimeter (PerkinElmer Ltd., Buckinghamshire, U.K.) at a concentration of $5 \mathrm{mg} / \mathrm{mL}$ in UV grade dichloromethane, with cell length of $1 \mathrm{dm}$.

Syntheses of compounds ( \pm )-cis-1, 2 and $\mathbf{3}$ have been already described. ${ }^{1}$

\section{Scheme $1^{\mathrm{a}}$}




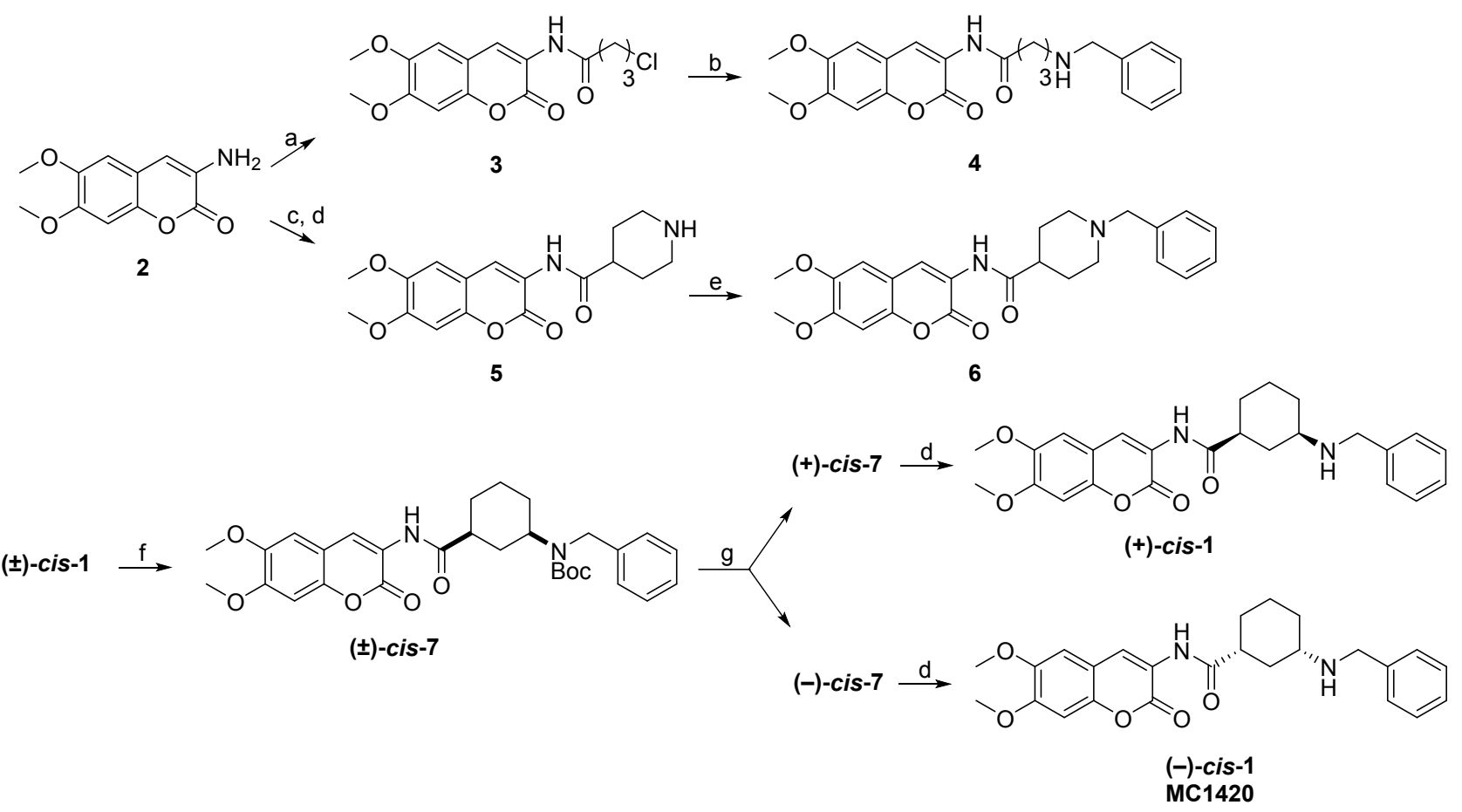

(a) Reagents and conditions: (a), 4-chlorobutyryl chloride, THF, triethylamine, rt; (b), benzylamine, KI, acetone, rt; (c), N-Boc protected isonipecotic acid, $\mathrm{HOBt}, \mathrm{DIC}, \mathrm{CH}_{2} \mathrm{Cl}_{2}$, rt; (d), TFA, $\mathrm{CH}_{2} \mathrm{Cl}_{2}, 0{ }^{\circ} \mathrm{C}$. (e), benzyl bromide, $\mathrm{K}_{2} \mathrm{CO}_{3}$, acetone, rt; (f) $\mathrm{Boc}_{2} \mathrm{O}$, THF, rt; (g) semi-preparative chiral HPLC.

\subsection{Synthesis of 4-(benzylamino)-N-(6,7-dimethoxy-2H-2-oxochromen-3-yl)butyramide}

\section{hydrochloride (4)}

$121 \mathrm{mg}(0.4 \mathrm{mmol})$ of $\mathbf{3}^{1}$ (Scheme 1) dissolved in $3 \mathrm{~mL}$ of anhydrous acetone were added portionwise to a solution of $436 \mu \mathrm{L}(0.4 \mathrm{mmol})$ of benzylamine in $3 \mathrm{~mL}$ of anhydrous acetone held at reflux. After $24 \mathrm{~h}$ the reaction was warmed to room temperature and the solvent was evaporated under vacuum. The crude oil was purified by column chromatography (eluent $\mathrm{CH}_{2} \mathrm{Cl}_{2} / \mathrm{MeOH} 9: 1$ ). The oil obtained by purification was treated with $1 \mathrm{~mL}$ of $\mathrm{HCl} 1.25 \mathrm{~N}$ in ethanol yielding 4 as hydrochloride: yield 45\%. MP 145-7 ${ }^{\circ} \mathrm{C}(\mathrm{dec})$; ${ }^{1} \mathrm{H}-\mathrm{NMR}\left(\mathrm{DMSO}-d_{6}\right) \delta: 1.94$ (qn, 2H, J = 8.0 Hz), $2.57(\mathrm{t}, 2 \mathrm{H}, \mathrm{J}=8.0 \mathrm{~Hz}) ; 2.97(\mathrm{br}, 2 \mathrm{H}) ; 3.80(\mathrm{~s}, 3 \mathrm{H}) ; 3.84(\mathrm{~s}, 3 \mathrm{H}) ; 4.58(\mathrm{~s}, 2 \mathrm{H}) ; 6.98-7.52(\mathrm{~m}, 7 \mathrm{H})$; 8.57 (s, 1H); 8.89 (br, 2H, exch. $\mathrm{D}_{2} \mathrm{O}$ ); 9.10 (br, 1H, exch. $\mathrm{D}_{2} \mathrm{O}$ ). ESI-MS m/z: 395.4 [M-H]Analytical calculated \% for $\mathrm{C}_{22} \mathrm{H}_{24} \mathrm{~N}_{2} \mathrm{O}_{5} \cdot \mathrm{HCl} \mathrm{C} 61.04 ; \mathrm{H} 5.82 ; \mathrm{N} 6.47$; found $\mathrm{C} 60.79 ; \mathrm{H} 6.02 ; \mathrm{N}$ 6.54 .

\subsection{Synthesis of N-(6,7-dimethoxy-2H-2-oxochromen-3-yl)piperidine-4-carboxamide (5)}


$136 \mathrm{mg}(0.54 \mathrm{mmol})$ of commercial N-Boc-piperidine-4-carboxylic acid and $90 \mathrm{mg}(0.54 \mathrm{mmol})$ of 1-hydroxybenzotriazole were dissolved in $10 \mathrm{~mL}$ of anhydrous dichloromethane (DCM). After 5 min. the reaction was cooled to $0{ }^{\circ} \mathrm{C}$ trough an external ice bath and $92 \mu \mathrm{L}(0.54 \mathrm{mmol})$ of N,Ndiisopropylcarbodiimide were added dropwise. After $5 \mathrm{~min} 60 \mathrm{mg}(0.27 \mathrm{mmol})$ of $2^{1}$ were added (Scheme 1) and the reaction was slowly warmed to room temperature and stirred for $36 \mathrm{~h}$. The mixture was filtered and the solvent was removed by rotatory evaporation. The resulting oil was concentrated to dryness yielding a brown solid. Purification by column chromatography (eluent ethyl acetate/n-hexane 2:1) afforded 1-Boc-N-(6,7-dimethoxy-2H-2-oxochromen-3-yl)piperidine-4carboxamide as yellow solid: yield 98\%. ESI-MS m/z: $455[\mathrm{M}+\mathrm{Na}]^{+}, 431[\mathrm{M}-\mathrm{H}]^{-} .146 \mathrm{mg}(0.27$ mmol) of this intermediate were dissolved in $3 \mathrm{~mL}$ of a solution of TFA $50 \%$ in DCM at $0^{\circ} \mathrm{C}$ with stirring for $15 \mathrm{~min}$. The reaction mixture was then warmed to room temperature and stirred for $5 \mathrm{~h}$. The resulting acid solution was neutralized with $\mathrm{NaHCO}_{3}$, the inorganic precipitate filtered off and washed with DCM. The solution was extracted with DCM $(3 \times 20 \mathrm{~mL})$ and the organic layers were collected and dried over anhydrous $\mathrm{Na}_{2} \mathrm{SO}_{4}$. The solvent was removed by rotatory evaporation yielding an orange solid: yield 84\%. ${ }^{1} \mathrm{H}-\mathrm{NMR}$ (acetone- $\left.d_{6}\right) \delta: 1.62-1.76(\mathrm{~m}, 2 \mathrm{H}) ; 1.92-1.96(\mathrm{~m}, 2 \mathrm{H})$; 2.74-2.79 (m, 2H); 2.96-3.26 (m, 2H); 3.86-3.69 (m, 1H); $3.90(\mathrm{~s}, 3 \mathrm{H}) ; 3.93(\mathrm{~s}, 3 \mathrm{H}) ; 5.03$ (br, $1 \mathrm{H}$, exch. $\left.\mathrm{D}_{2} \mathrm{O}\right) ; 6.98(\mathrm{~s}, 1 \mathrm{H}) ; 7.22(\mathrm{~s}, 1 \mathrm{H}) ; 8.58$ (br, $1 \mathrm{H}$, exch. $\left.\mathrm{D}_{2} \mathrm{O}\right) ; 8.65$ (s, 1H). ESI-MS m/z : 355.4 $\left[\mathrm{C}_{17} \mathrm{H}_{20} \mathrm{~N}_{2} \mathrm{O}_{5}+\mathrm{Na}\right]^{+}$.

\subsection{Synthesis of 1-benzyl-N-(6,7-dimethoxy-2H-2-oxochromen-3-yl)piperidine-4-carboxamide (6)}

$67 \mathrm{mg}(0.15 \mathrm{mmol})$ of 5 (Scheme 1$)$ and $10 \mathrm{mg}(0.7 \mathrm{mmol})$ of $\mathrm{K}_{2} \mathrm{CO}_{3}$ were suspended in $2 \mathrm{~mL}$ of anhydrous acetone. $0.018 \mathrm{~mL}(0.15 \mathrm{mmol})$ of benzyl bromide were added and the mixture stirred for $24 \mathrm{~h}$ at room temperature. The salt was filtered and washed with acetone and THF and the solvent was concentrated under vacuum. A brown solid was obtained and purified by column chromatography (eluent DCM/MeOH 95:5) yielding a yellow solid: yield 65\%. MP 151-4 ${ }^{\circ} \mathrm{C}(\mathrm{dec})$. ${ }^{1} \mathrm{H}-\mathrm{NMR}\left(\mathrm{CDCl}_{3}\right)$ $\delta: 2.11-2.18(\mathrm{~m}, 2 \mathrm{H}) ; 2.68-2.78(\mathrm{~m}, 4 \mathrm{H}) ; 3.23-3.38(\mathrm{~m}, 2 \mathrm{H}) ; 3.79-3.83(\mathrm{~m}, 1 \mathrm{H})$; 3.91 (s, 3H); 3.93 (s, 2H); 3.94 (s, 3H); 6.83-6.92 (m, 3H); 7.44-7.49 (m, 4H); 7.71 (br, 1H, exch. $\left.\mathrm{D}_{2} \mathrm{O}\right) ; 8.58(\mathrm{~s}, 1 \mathrm{H})$. ESI-MS m/z: $445.3[\mathrm{M}+\mathrm{Na}]^{+}, 421.3[\mathrm{M}-\mathrm{H}]^{-}$. Analytical calculated \% for $\mathrm{C}_{24} \mathrm{H}_{26} \mathrm{~N}_{2} \mathrm{O}_{5}$ C 68.23; H 6.20; N 6.63; found C 68.44; H 6.41; N 6.36.

\section{Chromatographic resolution of $( \pm)$-cis-1.}


$125 \mathrm{mg}$ of chromatographically pure $( \pm)$-cis-1 $(0.28 \mathrm{mmol})$ were dissolved in $5 \mathrm{~mL}$ of anhydrous THF; $87 \mathrm{mg}$ of di-t-butyldicarbonate $(0.40 \mathrm{mmol})$ were added and the solution stirred at room temperature for $6 \mathrm{~h}$ (Scheme 1). The solvent was evaporated to dryness and the crude residue purified on column chromatography (eluent ethyl acetate/n-hexane 1:1), giving $( \pm)$-cis-7 in quantitative yield.

The separation of the two enantiomers (+)-cis-7 and (-)-cis-7 was carried out with a Kromasil 5AmyCoat $(21.2 \times 250 \mathrm{~mm})$ chiral stationary phase with isopropanol $/ \mathrm{n}$-hexane $1: 1 \mathrm{v} / \mathrm{v}$ as the eluent (flow rate $15 \mathrm{~mL} / \mathrm{min} ; \lambda=220 \mathrm{~nm}) .(+)-7, \mathrm{t}_{R}=9.8 \mathrm{~min} ;[\alpha]_{D} 25=+34 \mathrm{deg} \cdot \mathrm{mL} \cdot \mathrm{dm}^{-1} \cdot \mathrm{g}^{-1}(5 \mathrm{mg} / \mathrm{mL}$; DCM). (-)-7, $\mathrm{t}_{R}=14.5 \mathrm{~min} ;[\alpha]_{D}^{25}=-34 \mathrm{deg} \cdot \mathrm{mL} \cdot \mathrm{dm}^{-1} \cdot \mathrm{g}^{-1}(5 \mathrm{mg} / \mathrm{mL} ; \mathrm{DCM})$.

After separation, compounds (+)-7 and (-)-7 (48 $\mathrm{mg}$ each, $0.09 \mathrm{mmol})$ were deprotected by dissolving them in $3 \mathrm{~mL}$ of trifluoroacetic acid $10 \%$ in $\mathrm{DCM}$ at $0{ }^{\circ} \mathrm{C}$. After the same workup described above for $\mathbf{5}$, pure final compounds were obtained in quantitative yield. ${ }^{1} \mathrm{H}-\mathrm{NMR}$ and ESIMS spectra were fully consistent with those previously described for $( \pm)$-cis-1. ${ }^{1}$ Both free bases were crystallized as hydrochloride from a solution of $\mathrm{HCl} 1.25 \mathrm{~N}$ in ethanol: $\mathrm{MP} 193-5{ }^{\circ} \mathrm{C}(\mathrm{dec})$. Analytical calculated \% for $\mathrm{C}_{25} \mathrm{H}_{28} \mathrm{~N}_{2} \mathrm{O}_{5} \cdot \mathrm{HCl} \cdot 1.5 \mathrm{H}_{2} \mathrm{O} \mathrm{C} 60.06$; H 6.45; N 5.60; found (+)-cis-1 C 60.04; H 6.19; N 5.51; (-)-cis-1 C 59.77; H 6.26; N 5.61. (+)-cis-1, $[\alpha]_{\mathrm{D}}{ }^{25}=+50 \mathrm{deg} \cdot \mathrm{mL} \cdot \mathrm{dm}^{-1} \cdot \mathrm{g}^{-1}$ $(5 \mathrm{mg} / \mathrm{mL} ; \mathrm{DCM}) ;(-)-c i s-1,[\alpha]_{\mathrm{D}}{ }^{25}=-50 \mathrm{deg} \cdot \mathrm{mL} \cdot \mathrm{dm}^{-1} \cdot \mathrm{g}^{-1}(5 \mathrm{mg} / \mathrm{mL} ; \mathrm{DCM})$.

\section{Enzyme inhibition assays}

Inhibition of human acetylcholinesterase (hAChE) in phosphate buffer $\mathrm{pH} 8.0$ was assessed by means of the classical Ellman's assay, ${ }^{2}$ implemented on a 96-well plate procedure. ${ }^{3}$ Butyrylcholinesterase $(h \mathrm{BChE})$ was also assayed to assess $\mathrm{AChE} / \mathrm{BChE}$ selectivity. Inhibition kinetics of $( \pm)$-cis-1 and its enantiomers were determined for $h \mathrm{AChE}$ (Table 1). Acetyl- or butyrylthiocholine iodide were used as substrate and 5,5'-dithiobis(2-nitrobenzoic acid) (DTNB) as the chromophoric reagent. All enzymes and reagents were purchased from Sigma Aldrich Italy. Solutions of tested compounds were prepared starting from $10 \mathrm{mM}$ stock solutions in DMSO, that were diluted with aqueous assay medium to a final content of organic solvent always lower than $1 \%$. ChE-catalyzed hydrolysis was followed by measuring the increase of absorbance at $412 \mathrm{~nm}$ every $30 \mathrm{sec}$ for $5 \mathrm{~min}$ at $25{ }^{\circ} \mathrm{C}$ using a 96-well microplate reader Infinite M1000 Pro (Tecan, Milan, Italy). The concentration of compound which yielded 50\% inhibition of the ChE activity $\left(\mathrm{IC}_{50}\right)$ was calculated by non-linear regression of the response-log(concentration) curve, using GraphPad Prism (GraphPad Prism version 5.00 for Windows, GraphPad Software, San Diego, CA, 
USA). Kinetic studies were performed in the same incubation conditions, using six concentrations of substrate (from 0.033 to $0.200 \mathrm{mM}$ ) and four concentrations of inhibitor in a range comprising the $\mathrm{IC}_{50}$ value. Inhibition constants and kinetic parameters were calculated within the "Enzyme kinetics" module of Prism.

\section{MTT assays.}

Cytotoxicity of compound $( \pm)$-cis-1 was assayed on HepG2 human liver cancer cell line and on Madin-Darby canine kidney cells (MDCK-MDR1), by a MTT-based assay previously described. ${ }^{4}$ Briefly, viable cells were seeded in a sterile 96-well plate Cell Culture Cluster (Corning, NY, USA) and incubated with different concentrations of tested compounds for $2 \mathrm{~h}$ (on HepG2 cells), 24 and $72 \mathrm{~h}$ (on MDCK-MDR1 cells) at $37^{\circ} \mathrm{C}$ in $5 \% \mathrm{CO}_{2}$. At the end of incubation, the culture medium was replaced by a solution of MTT $0.5 \mathrm{mg} / \mathrm{mL}$ in PBS. After $4 \mathrm{~h}$ incubation at $37{ }^{\circ} \mathrm{C}$ in $5 \% \mathrm{CO}_{2}$ the supernatants were aspirated and $100 \mu \mathrm{L}$ of DMSO were added to each well. The absorbance at 570 $\mathrm{nm}$ was measured using a plate reader Victor V3 (Perkin-Elmer, Milan, Italy). Results are expressed as the percentage of MTT reduction respect to control cells. All experiments were carried out in sextuplicate and were repeated twice.

\section{Permeability assays.}

Blood-brain barrier permeability was estimated with a cellular model using transfected MadinDarby canine kidney cells (MDCK-MDR1) expressing P-glycoprotein (P-gp), ${ }^{5}$ as previously described. ${ }^{6}$ Briefly, MDCK-MDR 1 cells were seeded at a concentration of $1 \times 10^{5}$ cells per well on the apical side of Transwell inserts, in DMEM medium supplemented with $10 \%$ heat-inactivated fetal bovine serum (FBS), $100 \mathrm{U} / \mathrm{mL}$ penicillin, $100 \mu \mathrm{g} / \mathrm{mL}$ streptomycin and $2 \mathrm{mM}$ L-glutamine (EuroClone, Milan, Italy). Cells were maintained at $37{ }^{\circ} \mathrm{C}, 5 \% \mathrm{CO}_{2}$, and saturated humidity. Monolayer formation (approximately 8 days after seeding) was monitored by microscopy, and the TEER (Trans Epithelial Electrical Resistance) was measured every day using an EVOM electrode epithelial volt-ohm meter (World Precision Instruments, Friedberg, Germany). Formation of tight junctions was assessed by measuring the flux of the transcellular standard diazepam $(75 \mu \mathrm{M})$ and of paracellular standard fluorescein isothiocyanate-dextran (FD4, Sigma) (200 $\mu \mathrm{g} / \mathrm{mL})$ from the apical to the basolateral compartment. These probes were quantified with a PE double-beam UV-visible spectrophotometer Lambda Bio 20 (PerkinElmer, Milan, Italy) and a Victor3 fluorimeter (Wallac Victor3, 1420 Multilabel Counter, Perkin-Elmer) at excitation and emission wavelengths of 485 and 
$535 \mathrm{~nm}$, respectively. The apparent permeabilities $\left(\mathrm{P}_{\text {app }}\right)$, in units of $\mathrm{cm} / \mathrm{sec}$, in both directions, were calculated using the following equation $\mathrm{S} 1$ :

$$
\mathrm{P}_{\mathrm{app}}=\left(\mathrm{V}_{\mathrm{a}} / \text { area } \times \text { time }\right) \times([\text { Drug }] \text { acceptor } /[\text { Drug }] \text { initial })
$$

where " $\mathrm{V}_{\mathrm{a}}$ " is the volume in the acceptor well, "area" is the surface area of the membrane, "time" is the total transport time, "[Drug] acceptor" is the concentration of the drug measured by UVspectroscopy and "[Drug] initial" is the initial drug concentration in the Apical (AP) or Basolateral (BL) chamber.

To assess the $\mathrm{P}_{\text {app }} \mathrm{AP}$ or $\mathrm{BL}$, across the BBB, $( \pm)$-cis-1 was added to the apical or to basolateral compartment of the Transwell model in $0.5 \mathrm{~mL}$ or $1.5 \mathrm{~mL}$ of PBS (EuroClone, Milan, Italy), respectively, at a concentration of $75 \mu \mathrm{M}$. The receiving compartments contained $1.5 \mathrm{~mL}$ or $0.5 \mathrm{~mL}$ of PBS, respectively. After $2 \mathrm{~h}$ of incubation, the medium in the apical and basolateral compartments were collected separately. ( \pm )-cis-1 was quantified through UV-visible spectroscopy using the UV-visible spectrophotometer Lambda Bio 20 equipped with $10 \mathrm{~mm}$ path-length-matched quartz cells. $\mathrm{P}_{\text {app }}$ AP $(\mathrm{cm} / \mathrm{sec})$ and $\mathrm{P}_{\text {app }} \mathrm{BL}(\mathrm{cm} / \mathrm{sec})$ were calculated as described above. The efflux ratio (ER) was calculated using the following equation $\mathrm{S} 2$ :

$$
\mathrm{ER}=\left(\mathrm{P}_{\mathrm{app}}, \mathrm{BL}-\mathrm{AP}\right) /\left(\mathrm{P}_{\mathrm{app}}, \mathrm{AP}-\mathrm{BL}\right) \quad(\text { eq. } \mathrm{S} 2)
$$

$\mathrm{P}_{\text {app }}$, BL-AP: apparent permeability of basal-to-apical transport; $\mathrm{P}_{\text {app }}$, AP-BL: apparent permeability of apical-to-basal transport. An efflux ratio greater than 2 indicates that a test compound is likely to be a substrate for P-gp transport.

Table S1. MDCK-MDR1 cell MTT assay. ${ }^{\text {a }}$

\begin{tabular}{cccc}
\hline \multirow{2}{*}{ Entry } & \multicolumn{2}{c}{$\%$ cell viability at $[\mathrm{drug}]=\mathbf{1 0 0} \boldsymbol{\mu M}$} & $\mathbf{I C}_{\mathbf{5 0}}(\boldsymbol{\mu M M})$ \\
\cline { 2 - 3 } & $\mathbf{2 4} \mathbf{~ h}$ & $\mathbf{7 2 ~} \mathbf{~}$ & $\mathbf{7 2 ~} \mathbf{~}$ \\
\hline$( \pm)$-cis-1 & $60 \pm 2$ & $37 \pm 2$ & $30.2 \pm 1.6$ \\
\hline
\end{tabular}

(a) Values are mean \pm SEM of three independent experiments.

\section{Hydration calculations.}

Hydration calculations were performed on MC1420 independently from crystallographic data, to identify protein-ligand interactions mediated by water molecules, by using WET, ${ }^{7}$ a python script included in the AUTODOCK v. 4.2 docking suite. ${ }^{8}$ The hydration procedure consists of the following steps: i) H-bond donors and acceptors in the ligand are recognized; ii) the ligand is 
saturated with water molecules along H-bond vectors from the heavy atoms; iii) water molecules positions are checked against experimental occurrences. ${ }^{9-12}$ The procedure provides 12 water molecules, two of them that are involved in H-bonds with oxygen of the amidic group of the ligand and $\mathrm{N}$ of the amidic group of Phe288. Such interactions are similar to that of the experimentally obtained W1 water molecule. Figure S1 shows that water molecules obtained by WET (cyan spheres) are close to W1 water molecule (red sphere).

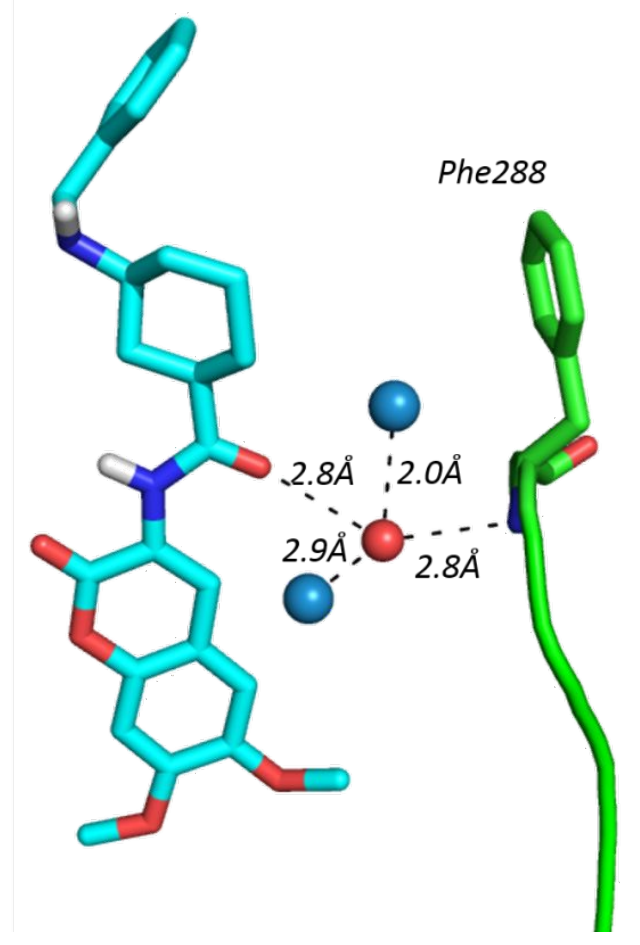

Figure S1. Water-mediated interaction of MC1420 with $T c \mathrm{AChE}$. The ligand (cyan) and Phe288 (green) are both shown as sticks. Water molecules placed according to the experimental electron density map (W1, red sphere) and obtained by the hydration procedure (cyan spheres) are shown. Bonds between water molecules, and H-bond interactions mediated by waters, are shown by dashed lines. 

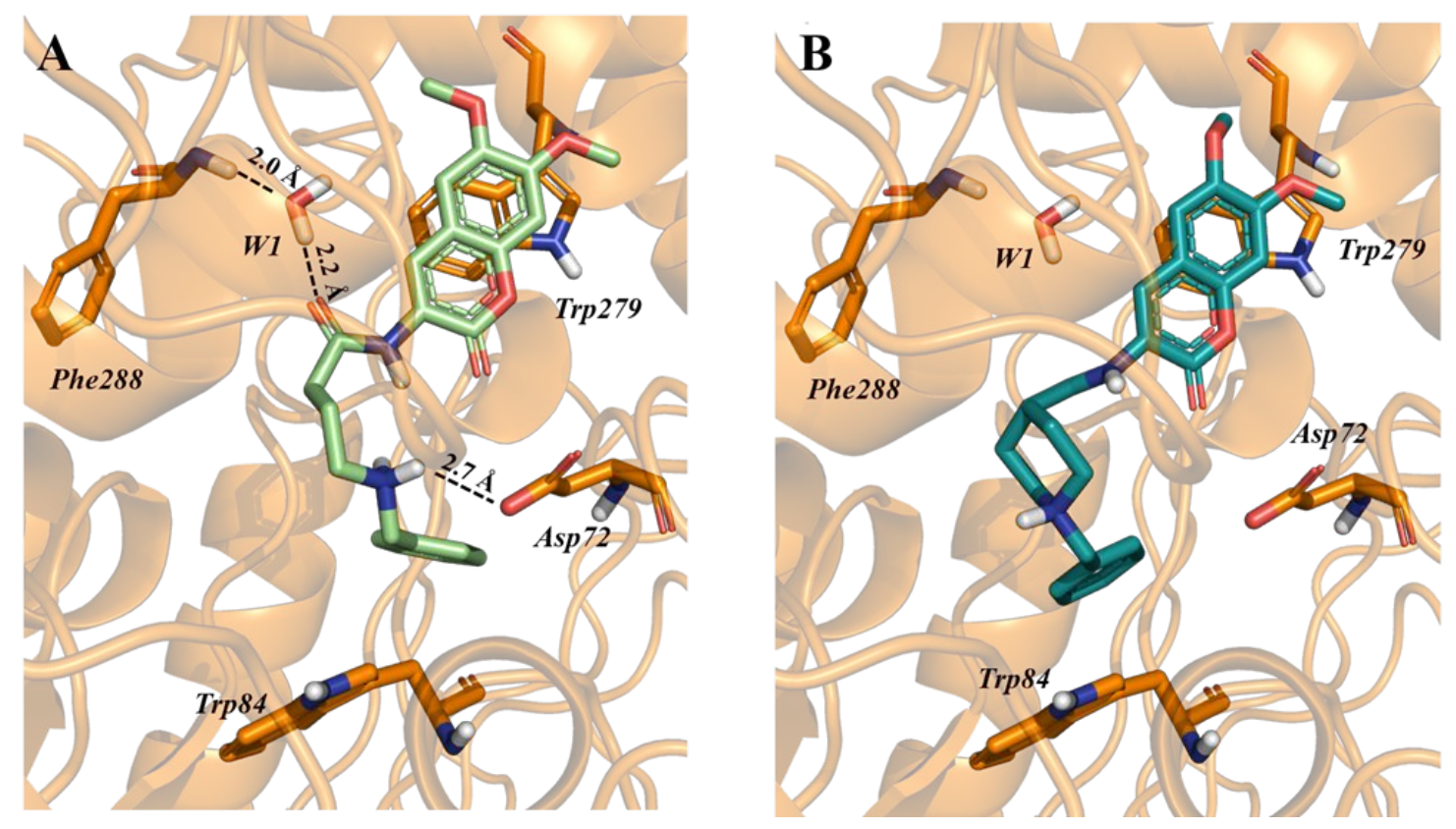

Figure S2. Top-scored docking poses of 4 (A) and 6 (B) within the binding site of TcAChE. The ligand itself, relevant amino acid residues, and the water molecule $\mathrm{W} 1$ responsible for water-mediated interaction with Phe288, are all rendered as sticks, while protein is represented as cartoon. H-bonds are depicted by dotted lines.

Table S2. Data collection and refinement statistics.

\begin{tabular}{|l|l|}
\hline & MC1420 \\
\hline PDB ID & $6 \mathrm{TT} 0$ \\
\hline Wavelength $(\AA)$ & 1.074 \\
\hline Resolution range & $39.48-2.8(2.9-2.8)$ \\
\hline Space group & P 3121 \\
\hline Unit cell & $\begin{array}{l}111.42 \quad 111.42 \quad 137.3790 \\
120\end{array}$ \\
\hline Total reflections & $44657(4385)$ \\
\hline Unique reflections & $24409(2405)$ \\
\hline Multiplicity & $1.8(1.8)$ \\
\hline Completeness $(\%)$ & $98.06(98.81)$ \\
\hline Mean I/sigma(I) & $10.50(1.57)$ \\
\hline
\end{tabular}




\begin{tabular}{|l|l|}
\hline Wilson B-factor & 69.73 \\
\hline R-merge & $0.04067(0.3768)$ \\
\hline R-meas & $0.05751(0.5328)$ \\
\hline R-pim & $0.04067(0.3768)$ \\
\hline CC1/2 & $0.998(0.872)$ \\
\hline CC* & $1(0.965)$ \\
\hline Reflections used in refinement & $24321(2407)$ \\
\hline Reflections used for R-free & $1189(124)$ \\
\hline R-work & $0.1896(0.3374)$ \\
\hline R-free & $0.2370(0.3933)$ \\
\hline CC(work) & $0.958(0.862)$ \\
\hline CC(free) & $0.957(0.705)$ \\
\hline Number of non-hydrogen atoms & 4392 \\
\hline Macromolecules & 4244 \\
\hline Ligands & 60 \\
\hline Solvent & 88 \\
\hline Protein residues & 532 \\
\hline RMS(bonds) & 0.012 \\
\hline RMS(angles) & 1.08 \\
\hline Ramachandran favored (\%) & 93.58 \\
\hline Ramachandran allowed (\%) & 6.04 \\
\hline Ramachandran outliers (\%) & 0.38 \\
\hline Rotamer outliers (\%) & 5.38 \\
\hline Clashscore & 9.02 \\
\hline Average B-factor & 69.92 \\
\hline Macromolecules & 69.82 \\
\hline Ligands & 77.83 \\
\hline Solvent & 69.26 \\
\hline
\end{tabular}

*Statistics for the highest-resolution shell are shown in parentheses. 


\section{References}

1. Catto, M.; Pisani, L.; Leonetti, F.; Nicolotti, O.; Pesce, P.; Stefanachi, A.; Cellamare, S.; Carotti, A. Design, Synthesis and Biological Evaluation of Coumarin Alkylamines as Potent and Selective Dual Binding Site Inhibitors of Acetylcholinesterase. Bioorg. Med. Chem. 2013, 21, 146-152.

2. Ellman, G. L.; Courtney, K. D.; Andres, V., Jr.; Feartherstone, R. M. A New and Rapid Colorimetric Determination of Acetylcholinesterase Activity. Biochem. Pharmacol. 1961, 7, 88-95.

3. Pisani, L.; Catto, M.; De Palma, A.; Farina, R.; Cellamare, S.; Altomare, C. D. Discovery of Potent Dual Binding Site Acetylcholinesterase Inhibitors via Homo- and Heterodimerization of Coumarin-Based Moieties. ChemMedChem 2017, 12, 1349-1358.

4. Berridge, M. V.; Tan, A. S. Characterization of the Cellular Reduction of 3-(4,5-Dimethylthiazol2-yl)-2,5-diphenyltetrazolium Bromide (MTT): Subcellular Localization, Substrate Dependence, and Involvement of Mitochondrial Electron Transport in MTT Reduction. Arch. Biochem. Biophys. 1993, 303, 474-482.

5. Franchini, S.; Manasieva, L.I.; Sorbi, C.; Battisti, U. M.; Fossa, P.; Cichero, E.; Denora, N.; Iacobazzi, R. M.; Cilia, A.; Pirona, L.; Ronsisvalle, S.; Aricò, G.; Brasili, L. Synthesis, Biological Evaluation and Molecular Modeling of 1-Oxa-4-thiaspiro- and 1,4-Dithiaspiro[4.5]decane Derivatives as Potent and Selective 5-HT $1 \mathrm{~A}$ Receptor Agonists. Eur. J. Med. Chem. 2017, 125, 435452.

6. Pisani, L.; Farina, R.; Soto-Otero, R.; Denora, N.; Mangiatordi, G. F.; Nicolotti, O.; MendezAlvarez, E.; Altomare, C. D.; Catto, M.; Carotti, A. Searching for Multitargeting Neurotherapeutics against Alzheimer's: Discovery of Potent AChE-MAO B Inhibitors through the Decoration of 2HChromen-2-one Structural Motif. Molecules 2016, 21, 362. 
7. Forli, S.; Olson, A. J. A Force Field with Discrete Displaceable Waters and Desolvation Entropy for Hydrated Ligand Docking. J. Med. Chem. 2012, 55, 623-638.

8. Morris, G. M.; Huey, R.; Lindstrom, W.; Sanner, M. F.; Belew, R. K.; Goodsell, D. S.; Olson, A. J. Autodock4 and AutoDockTools4: Automated Docking with Selective Receptor Flexibility. J. Comput. Chem. 2009, 16, 2785-2791.

9. Taylor, R.; Kennard, O.; Versichel, W. Geometry of the Imino-Carbonyl (N-H...O:C) Hydrogen Bond. 1. Lone-Pair Directionality. J. Am. Chem. Soc. 1983, 105, 5761-5766.

10. Wiberg, K.; Marquez, M.; Castejon, H. Lone Pairs in Carbonyl-Compounds and Ethers. J. Org. Chem. 1994, 59, 6817-6822.

11. Lommerse, J. P. M.; Price, S. L.; Taylor, R. Hydrogen Bonding of Carbonyl, Ether, and Ester Oxygen Atoms with Alkanol Hydroxyl Groups. J. Comput. Chem. 1997, 18, 757-774.

12. Nobeli, I.; Price, S. L.; Lommerse, J. P. M.; Taylor, R. Hydrogen Bonding Properties of Oxygen and Nitrogen Acceptors in Aromatic Heterocycles. J. Comput. Chem. 1997, 18, 2060-2074. 